\title{
Preliminary Laboratory Studies on Increasing Phosphorus Availability In Eppawala Apatite
}

\author{
C. S. WEERARATNE*
}

Department of Agricultural Chemistry, Faculty of Agriculture, University of Peradeniya, Peradeniya, Sri Lanka.

(Date of receipt: 08 June 1979)

(Date of acceptance: 28 April 1983)

\begin{abstract}
Preliminary investigations to increase the availability of phosphorus in Eppawala apatite were carried out. Samples of an ultisol (Reddish. Brown Latasolic soil) and an alfisol (Reddish Brown Earths) amended with animal manure or straw or sulphur at $2 \%$ were incubated separately with finely ground apatite at $50 \%$ field capacity or under flooded condition. Olsen's $\mathrm{P}$ of the incubated soil samples determined at fortnightly periods indicate that the release of phosphorus in apatite is increased by straw and animal manure under unflooded conditions. Under flooded conditions only animal manure was effective. Straw did not show any significant influence.
\end{abstract}

\section{Introduction}

Phosphate rock is one of the primary raw materials of the world's chemical fertilizer plants. Apatite is an important phosphate rock of igneous origin and deposits of this material in various forms occur in a number of countries. ${ }^{17}$ In Sri Lanka, large deposits of apatite are known to occur in Eppawala in Anuradhapura District. The plant available $P$ in apatites is generally low ${ }^{11.21}$ and hence, processing of this material to increase its $P$ availability is usually carried out. As this process involves energy and other raw materials the final product tends to be more expensive.

Various methods of increasing the $\mathbf{P}$-availability in apatite materials such as applying the fertilizer material a few weeks before planting the crop ${ }^{20}$, incorporation of sulphur ${ }^{3}$ or animal manure ${ }^{18}$ along with apatite are shown to be effective. As availability of $P$ in apatite is usually greater in acidic soils, ${ }^{1}$ studies were carried out to examine the influence of mixing Eppawala apatite with acidifying materials on $P$ availability under upland and lowland conditions.

\section{Materials and Methods}

Soil samples ( $<2 \mathrm{~mm}$ in diameter) of two tropical soils viz. Reddish Brown Latasolic (RBI.) and Reddish Brown Earths (RBE), finely ground sulphur and lightly ground particles ( $<2 \mathrm{~mm}$ ) of straw and animal manure (cattle dung) were used in the study. The phosphate rock material used was a finely ground sample of apatite deposits found in Eppawala located in the North Central Province of Sri Lanka. The total and Olsen's $\mathbf{P}$ of the materials used are indicated in Table 1.

\footnotetext{
*Present address : Faculty of Agriculture, Ruhuna University, Matara, Sri Lanka.
} 


\section{Experiment 1}

Samples of Reddish Brown Latasolic (RBL) and Reddish Brown Earth (RBE) were mixed separately with dried animal manure (cattle dung), dried straw or powdered. sulphur at $2 \%$. The apatite material was also incorporated with these mixtures at the same rate and incubated at room temperature and at $50 \%$ field capacity over a period of 12 weeks. Controls (soils alone and soils mixed with cattle dung or straw or sulphur) were similarly incubated. At fortnightly intervals, samples taken from the incubating mixtures were analysed for Olsen's phosphorous' ${ }^{13}$ by blue colour method. ${ }^{10}$ Each treatment was triplicated.

\section{Experiment 2}

Soil mixtures except those with sulphur, prepared as in Experiment 1 were incubated under flooded conditions ( $1^{\prime \prime}$ water maintained above the soil level) at room temperature. Olsen's $\mathbf{P}$ was determined as in Experiment 1.

\section{Results and Discussion}

Olsen's $\mathrm{P}$ or $\mathrm{NaHCO}_{3}$ extractable $\mathrm{P}$ is considered a good indicator of the plant available phosphorus in a soil. ${ }^{13}$ During incubation of a soil, available $P$ content tends to increase due to mineralization of organic phosphorous by soil micro-organisms! ${ }^{15}$ Some of these organisms are capable of dissolving $\mathrm{P}$ containing minerals ${ }^{19}$ secreting organic acids such as $\propto-$ ketoglutonic ${ }^{8}$, lactic and acetic. ${ }^{18}$ Available $\mathrm{P}$ tends to decrease due to chemical factors! ${ }^{2}$ Thus, the available $P$ content, indicated by Olsen's $P,{ }^{13}$ at any moment depends on the net effects of these processes. Dissolution of phosphate rock depends to a great extent on the nature of the material itself ${ }^{4,5,7}$ and also on soil factors ${ }^{1.6}$

\section{Experiment 1}

Results of the first experiment (Tables 2 \& 3) indicate that during incubation, Olsen's $P$ in soil and apatite mixtures have increased gradually in the first 4-6 weeks and thereafter remains more or less constant in RBE or tends to decrease in RBL. As could be expected, incorporation of apatite has increased Olsen's $P$ over the control although the differences are not significant. Available $P$ in soils incubated with straw or cattledung also show a tendency to increase similar to that in the previous treatments. There is a significant increase in available $P$ in soils incubated with cattle-dung in RBL soils during the 4 th -8 th week and RBE soils during 2 nd -6 th week. This increase is likely to be due to high $\mathbf{P}$ content in cattle-dung (Table 1) which may have got partly solubilised during incubation. In soil-straw mixture, Olsen's $P$ has not significantly increased during incubation: This could be due to low P content of straw (Table 1) and microbial immobilization which is known to take place with an increase in the microbial population ${ }^{2}$ brought about by the incorporation of carbohydrate rich material such as straw. ${ }^{-14}$ 
Preliminary Laboratory Studies on Increasing Phosphorus Availability in Eppawala Apatitie

Table 1.- P contents of the materials used in the study (Average of 3 ).

\begin{tabular}{lcc}
\hline & Total P mg/100g & Olsen's P -ppm \\
\hline Reddish Brown Latasolic soil & 12.2 & 6.7 \\
Reddish Brown Earth soil & 8.4 & 12.4 \\
Apatite & 1280.0 & 0.6 \\
Cattle-dung (dried) & 176.1 & 0.8 \\
Straw (dried) & 12.4 & - \\
\hline
\end{tabular}

Table 2.- Olsen's of RBL samples incubated at $50 \%$ field capacity in ppm (Average of 3 ).

\begin{tabular}{lrrrrrrr}
\hline & \multicolumn{7}{c}{ Weeks } \\
& \multicolumn{1}{c}{0} & \multicolumn{1}{c}{ 2 } & \multicolumn{1}{c}{4} & \multicolumn{1}{c}{6} & \multicolumn{1}{c}{8} & 10 & 12 \\
\hline Soil & 6.6 & 8.9 & 9.6 & 9.7 & 10.5 & 10.2 & 9.8 \\
Soil + A & 6.6 & 10.1 & 10.4 & 11.1 & 11.4 & 10.9 & 10.2 \\
Soil + ST & 6.7 & 7.1 & 8.1 & 10.5 & 11.6 & 11.6 & 11.0 \\
Soil + CD & 7.4 & 10.2 & 12.8 & 12.6 & 12.7 & 12.6 & 11.7 \\
Soil + S & 6.9 & 8.7 & 9.4 & 8.6 & 9.8 & 9.2 & 9.0 \\
Soil + A + ST & 6.6 & 10.3 & 11.1 & 13.1 & 13.5 & 11.4 & 12.1 \\
Soil + A + CD & 7.6 & 11.7 & 14.6 & 15.2 & 13.7 & 13.9 & 12.4 \\
Soil + A + S & 6.8 & 8.8 & 10.2 & 9.8 & 9.6 & 10.1 & 10.2 \\
LSD 5\% & 1.4 & 1.6 & 1.4 & 1.6 & 1.3 & 2.7 & 2.4 \\
\hline
\end{tabular}
A - Apatite
ST - Straw
$\mathrm{CD}$ - Cattle-dung
$\mathrm{S}$-Sulphur 
Table 3.- Olsen's $P$ of RBE samples incubated at 50\% field capacity in ppm (Average of 3).

\begin{tabular}{lccccccc}
\hline & \multicolumn{7}{c}{ Weeks } \\
& 0 & 2 & 4 & 6 & 8 & 10 & 12 \\
\hline Soil & 12.2 & 14.3 & 14.7 & 15.3 & 15.7 & 15.4 & 15.7 \\
Soil + A & 12.8 & 15.5 & 16.1 & 16.2 & 16.0 & 16.3 & 16.0 \\
Soil + ST & 12.4 & 13.1 & 13.8 & 15.7 & 16.7 & 15.9 & 15.1 \\
Soil + CD & 12.2 & 17.1 & 17.8 & 18.4 & 18.8 & 18.9 & 18.8 \\
Soil + S & 12.3 & 15.2 & 14.9 & 15.4 & 16.2 & 16.1 & 16.4 \\
Soil + A + ST & 12.9 & 18.2 & 19.0 & 19.3 & 19.5 & 19.3 & 19.6 \\
Soil + A + CD & 12.4 & 19.2 & 20.7 & 21.0 & 20.8 & 21.6 & 20.6 \\
Soil + A + S & 13.1 & 15.3 & 16.5 & 16.4 & 16.5 & 16.4 & 16.8 \\
LSD 5\% & 1.8 & 1.6 & 2.5 & 2.3 & 2.5 & 2.9 & 2.1 \\
\hline
\end{tabular}
A - Apatite
ST - Straw
CD - Cattle-dung
$S$ - Sulphur

\section{Effect of organic matter}

In treatments where soil-organic matter mixtures are incubated with apatite, Olsen's $P$ has significantly increased over the corresponding controls. This increase is observed in the case of cattle-dung apatite mixture during the periods 4 th - 6 th and 2 nd - 6 th week in RBL and RBE respectively. Mixing apatite with straw also has increased the available P content significantly during the 2 nd -8 th and 2 nd -12 th week periods in RBL and RBE respectively. These results show that decomposing straw and cattledung have a solubilisation effect on apatite probably due to increased microbial activity which is known to cause production of acids. ${ }^{19}$ However, this effect appears to be more with straw than with cattle-dung and more in RBE than in RBL. Singh and Datta ${ }^{18}$ also reported that mixing farmyard manure with phosphate rock increased $P$
utilization by paddy.

\section{Effect of sulphur}

In soils incubated with sulphur, available $\mathrm{P}$ has increased but not significantly. This is so even when apatite is incorporated, indicating that incubating with sulphur has no net influence over $P$ availability. Singh and Datta ${ }^{18}$ also did not get consistent results in a $P$ utilization study in rice with sulphur but Bromfield ${ }^{3}$ found that incorporation of $\mathrm{S}$ increased $\mathrm{P}$ uptake in ground nut. 


\section{Experiment 2}

Under flooded conditions (Tables 4 and 5) too, available $P$ has increased during incubation even more than at $50 \%$ field capacity. When a soil is kept flooded, anaerobic conditions develop, red-ox potential drops and more soluble phosphorous compounds form 16 The inerease in $P$ availability under flooded conditions could be attributed to the above factors.

\section{Effect of organic matter}

Incubating with added organic materials enhance these factors resulting in an increase in available $\mathbf{P}$ due to solubilisation effect of the decomposing organic materials. With straw, Olsen's P has significantly increased in RBL after the 6th week and in RBE after the 8th week. With cattle-dung in RBL and RBE, available $\mathrm{P}$ has significantly increased after the 2 nd week. In soil organic matter mixtures incorporated with apatite, available $P$ has increased significantly over the corresponding controls only in the case of soil cattle-dung mixture. These observations indicate that during anaerobic decomposition of cattle-dung, insoluble $\mathbf{P}$ compounds in soil and apatite tend to get dissolved but when straw undergoes decomposition under flooded conditions, only soil $\mathbf{P}$ compounds tend to get mobilized.

Table 4. - Olsen's P of RBL samples incubated under flooded conditions in ppm (Average of 3).

\begin{tabular}{lrrrrrrr}
\hline & \multicolumn{7}{c}{ Weeks } \\
& \multicolumn{1}{c}{0} & \multicolumn{1}{c}{2} & \multicolumn{1}{c}{4} & \multicolumn{1}{c}{6} & 8 & 10 & 12 \\
\hline Soil & 7.3 & 9.6 & 10.5 & 11.2 & 11.6 & 12.2 & 12.6 \\
Soil + A & 7.4 & 11.2 & 14.0 & 14.2 & 15.1 & 15.9 & 16.0 \\
Soil + ST & 7.5 & 9.5 & 12.2 & 15.9 & 15.2 & 16.7 & 17.5 \\
Soil + CD & 8.1 & 13.5 & 14.5 & 14.5 & 16.6 & 16.3 & 15.7 \\
Soil + A + ST & 7.4 & 10.2 & 12.3 & 14.4 & 14.5 & 15.2 & 16.1 \\
Soil + A + CD & 8.5 & 15.4 & 16.5 & 18.1 & 19.7 & 18.7 & 20.0 \\
LSD 5\% & 1.6 & 1.7 & 1.8 & 2.1 & 1.6 & 2.1 & 2.0 \\
\hline
\end{tabular}
A - Apatite
ST - Straw
$C D=$ Cattle-dung

These results indicate that incorporation of organic materials such as cattledung and straw tend to increase availability of phosphorous in Eppawala apatite under unflooded conditions. As this increase takes place only for a limited period, 
applications of organic materials may have to be timed in order to obtain the maximum benefit of enhanced $\mathbf{P}$ availability. Under flooded condition, only cattledung appears to be effective in increasing $P$ availability in Eppawala apatite.

Table 5.- Olsen's P of RBE samples incubated under flooded conditions in ppm (Average of 3).

\begin{tabular}{|c|c|c|c|c|c|c|c|}
\hline & \multicolumn{7}{|c|}{ Weeks } \\
\hline & 0 & 2 & 4 & 6 & 8 & 10 & 12 \\
\hline Soil & 12.4 & 15.4 & 16.2 & 17.4 & 17.6 & 16.9 & 17.1 \\
\hline Soil + A & 12.8 & 16.4 & 17.4 & 18.2 & 18.9 & 18.4 & 18.5 \\
\hline Soil + ST & 13.2 & 14.8 & 16.4 & 18.8 & 21.4 & 20.8 & 21.4 \\
\hline Soil + CD & 13.1 & 17.5 & 19.5 & 19.8 & 20.1 & 20.4 & 20.3 \\
\hline Soil + A + ST & 12.9 & 14.5 & 16.3 & 18.2 & 20.8 & 20.4 & 20.6 \\
\hline Soil $+A+C D$ & 12.6 & 20.4 & 21.8 & 21.9 & 22.8 & 23.8 & 24.2 \\
\hline LSD 5\% & 1.8 & 2.0 & 2.2 & 2.0 & 2.4 & 2.6 & 2.6 \\
\hline
\end{tabular}

$$
\begin{aligned}
& \text { A - Apatite } \\
& \text { ST - Straw } \\
& \text { CD - Cattle-dung }
\end{aligned}
$$

\section{Acknowledgements}

A research grant was provided by the Natural Resources, Energy and Science Authority of Sri Lanka for carrying out the studies reported in this paper. Assistance given by Mr. I. M. Sirisena by typing the manuscript is gratefully acknowledged.

\section{References}

I. BAMES, J. S. \& KAMPRATH, E. J. (1975). Availability of North Carolina rock phosphate applied to soils. North Carolina Agric. Stn. Tech. Bull. 23 p.

2. BIRCH, M. F. (1961). Phosphorus transformation during plant decomposition Pl. Soil 15: $347-366$.

3. BROMFIELD, A. R. (1975). Effect of ground rock phosphate-sulphur mixture on yield and nutrient uprake of groundnuts in Northem Nigeria. Expl. Agric. 11: 265 - 272.

4. CARO, J. H. \& HILL, W. L. (1956). Characterisrics and fertilizer value of phosphave rock from different fields J. Agric. Food Chem. 4: $684-687$.

5. CHIEN, S. H. (1977). Thermodynamic consideration on the solubility of phosphate rock. Soil Sci. 123: 117-121.

6. CHIEN, S. H. (1977). Dissolution of phosphate rocks in a flooded acid soil. Soil Sci. Am. J.. 41: $1106-1109$.

7. CHIEN, S. H. \& BLACK, C. A. (1976). Free energy of formation of carbonate apatites in some phosphate rocks Soil Sci. Soc. Am. J. 40: $234-239$. 
8. DUFF, R. B., WEBLEY, D. M. \& SCOTT, R. O. (1963). Solubilisation of minerals and related materials by. 2 . ketogluconic acid producing bacteria. Soil Sci. 95: 105 - 114.

9. ENWEZOR, W. O. (1966). The biological transformation of phosphorus during the incubation of a soil treated with soluble inorganic phosphorus and with fresh and rotted organic materials. Pl. soil 25: 463 - 466.

10. JOHN, M. K. (1970).Colorimetric determination of phosphorus in soil and plant materials with ascorbic acid. Soil Sci. 109: $214-220$.

11. JONES, U. S. (1979). Fertilizers and Soil fertility, 1st edition. Virginia. Reston Pub. Co.

12. LARSEN, S., GUNNARY, D. \& SUTTON, C. D. (1965). The rate of immobilization of applied phosphate in relation to soil properties. J. Soil Sci. 16: $141-148$.

13. OLSEN, S, R. \& DEAN, L. A. (1965). Phosphorus. In C. A. Black ed. Methods of Soil analysis. p. 1044 Madison, Wisc. American Society of Agronomy.

14. PARKER, D. T. (1962). Decomposition in the field of buried and surface applied corstalk residue. Proc. Soil Sci. Am. 26: 559 - 562 .

15. PEARSON, R. W., NORMAN, A. G. \& CHUNG, H. O. (1941). The mineralisation of the organic phosphorus of various compounds in soil. Proc. Soil Sci. Soc. Am. 6: $168-175$.

16. PONNAMPERUMA, F. N. (1972). The chemistry of submerged soil. Adv. Agron. 24: 29 - 96.

17. SHELDON, R. P. (1978). Fertilizer raw materials status and outlook in Asia and the Pacific. Proc. Second INPUTS review meeting. Honolulu, Hawai. 249 - 254.

18. SINGH, D. \& DATTA, N. P. (1974). Saturation of soil with respect to P in relation to the efficiency of utilization of applied $P$ from indigenous phosphate rocks. J. Ind. Soc. Sci. 22: 125 - 129.

19. SPERBER, J. I. (1958). The incidence of apatite - solubilizing organisms in the rhizosphere and soil. Aust J. Agric. Res. 2. 779. - 782.

20. WEERARATNA, C. S. (1976). Some studies on phosphorus availability in Eppawala apatite. Trop. Agriculturist: $141-147$.

21. WEERARATNA, C. S. (1979). ${ }^{32}$ p studies on p availability in soils incubated with local and imported rock phosphorus and concentrated superphosphate in Isotopes and radiation in research on soil-plant relatianships. p 479 - 486. International Atomic Energy Agency, Vienna. 